\title{
Moral Gratitude to Ancestors in Worshiping Beliefs of Hung Vuong
}

\author{
Associate. Professor. Dr. Tran Đang Sinh \\ Hanoi National University of Education, Viet Nam \\ PhD student Mai Trong An Vinh \\ Hanoi National University of Education, Viet Nam
}

\begin{abstract}
Summary
Through the ritual of worshiping Hung Vuong, the Vietnamese send their gratitude to their ancestors. This ethic was formed and developed during the history of building and defending the country of the Vietnamese people, becoming the ethics and way of life of the Vietnamese people. The ethic of gratitude to ancestors in Hung Vuong worship belief shows morality with ancestors, it is the link between people in the national community. Since then, compassion and community character have been built, strengthened and developed.
\end{abstract}

Keywords: Ancestor, Hung Vuong, dogma, Worship, Gratitude to ancestors.

DOI: $10.7176 / \mathrm{JEP} / 12-9-07$

Publication date:March $31^{\text {st }} 2021$

\section{Preamble}

Worshiping Hung Vuong has become a traditional custom, has a very special place in the spiritual life of the Vietnamese people, is one of the elements that make up the cultural identity of Vietnam. Stemmed from the need of reality, the sense of "sharing the same source" is constantly fostered in the process of building and defending the country, is reasoned and institutionalized, becomes morality and live, create the cultural identity of the Vietnamese people. Typical of that consciousness are the legend of Lac Long Quan - Au Co and the anniversary of Hung Vuong's death anniversary.

\section{Research content}

The nature of Vietnamese people's worship of Hung Vuong is that Hung Vuong's belief that when living is wise, having merit the country, when dying, he is able to protect and help descendants to have a prosperous and happy life.

Based on the documents and research results of the fields of history, archeology, ethnography and folklore, we can confirm that the Hung Vuong era is a real era in history, The theory of Lac Long Quan - Au Co - Hung Vuong, although it is a legend and has a legendary color, reflects the historical core of that era. Along with the development of history, the perfecting process of the feudal autonomous state, the nation and the sense of national community - a sustainable nation, the legend of Hung Vuong - the religion of totem stamping divinization, step by step historicalization, has a clear secondary background and is strictly regulated in the worship rituals.

In the autumn of 1010, right after moving the capital from Hoa Lu (Ninh Binh) to Dai La, renamed Thang Long, with the intention of "building a permanent capital for everlasting and descending descendants", Ly Thai To said gather the gods of rivers and mountains nationwide to Thang Long, turning this place into a center of belief - religion, spiritual center of the country. God of Mount Tan Vien, god of Trong Dong (Dong Co), Thanh Giong, Hai Ba Trung, ... respectively, were deified by Ly kings and gathered to Thang Long. In Xuan Dinh village (customary called Fox village) right next to West Lake also formed the legend of Lac Long Quan - Au Co has helped people to explore this place and Mrs. Au Co gave birth to "a hundred eggs" in this area. . Obviously the concentration of power in secular is reflected in divine concentration (or divine concentration has helped the concentration of power in secular world!). However, the title and the Hung Vuong genealogies appeared much later. During the first large-scale national-wide-scale deification, in 1285, the Tran only canonized Phung Hung, Trieu Quang Phuc, Hai Ba Trung, Ly Nam De, Son Tinh, ... without mentioning Hung. United. According to the Vietnamese bibliography, the earliest mention of the title Hung Vuong is the Vietnamese work of u linh (a work of folklore with eccentric colors written in 1329, under the Tran dynasty). Thus, Hung Vuong is still in the legend of the folk, not entering the political history. In 1372, in the book Viet The Chi, Ho Tong Thuoc (with the position of Academy of Academician) was the first to introduce the history of the Hung Kings - both as an important historical figure that has been forgotten, both as a common spirit of the nation that descendants have the responsibility to commemorate and be filial to those who initiated the nation's construction. But it was not until 1470 that Le Thanh Tong allowed the bureaucrats to establish Hung Vuong genealogy with the clear historical status of 18 kings, with a whole day of death (cavalry), to be upgraded to the "International" rank with ritual the "National holiday" character is strictly codified according to the Confucian spirit, through the lenses of Vietnamese grapes. Hung Vuong is officially considered the "Holy King of a thousand times", The Holy Father looks after the 
realm and patronizes the spirituality of the Vietnamese people. Every year, on the occasion of Hung Vuong Festival, the king himself (or his representative is a high-ranking official) must come to Hung Vuong temple to celebrate the Holy Father. The Le dynasty also allowed the people of Hy Cuong commune to be the "eldest son of the generation", granted 500 acres of fields, collected taxes from Tuyen Quang and Hung Hoa areas to Viet Tri to make incense to worship.

Every year at King Hung Temple in Co Tich village, Lam Thao district, Phu Tho province, "international" is held and representatives of the court come to stand presiding at the death anniversary. People from all over the places flocked to Hung To Temple and even provinces also prayed to King Hung. Therefore, it is the most important death anniversary of the Vietnamese people. Hung Temple was built on Nghia Linh mountain in the middle of ancient Phong Chau land, now belongs to Co Tich village, Hy Cuong commune, Lam Thao district, Phu Tho province. Enter the gate, climb over 225 stone steps to reach Ha Temple, where it is said that Au Co lays hundreds of eggs, hatches into hundreds of children, 50 children follow his father Lac Long Quan down the coast, 49 children follow their mother to the mountain, leaving one eldest son to become the king of Van Lang country, that was the first King Hung Vuong. In front of Ha Temple is a 700-year-old Thien Tue tree, here, on August 19, 1954, Uncle Ho talked to the 308 Division's officers and soldiers who were tasked with taking over the capital. Uncle told: The Hung kings have built the country, we must keep together to keep the country. From Ha temple, over 168 stone steps, to Trung temple, it is said that Hung kings often together with the gods gather to discuss water here. Going back another 102 stone steps to Thuong temple, where the Hung Kings worshiped Heaven, Earth, God of Mountain, and Than Lua. The door of the temple has a large panel with four gilded words "Nam Quoc Son Ha". Usually, the festival starts from the seventh and eighth and lasts until December 11, 12. The Hung Temple's main festival is opened on the 10th of the third day of the lunar calendar every year, since ancient times by all Vietnamese people. Remember, consider the death anniversary:

Whoever goes back and forth,

Remember the tenth anniversary of the tenth anniversary.

Right on the 10th day, from early morning, many people flocked here to witness the sacrifice of King Hung. From the high-ranking representatives of the State to the ordinary people, everyone sincerely lit fragrant incense to express gratitude and pray that King Hung's soul would bless us, his family and his family. children of the country and for the destiny of the nation. Rituals, ceremonies, incense offerings, flower offerings, and wine offerings are conducted solemnly. People also presented to King Hung many offerings, especially thick cakes, banh chung to King Father and thanked the Hung Kings for teaching people to grow rice. After the ceremony, people carry out processions with contents related to the legend of Hung Vuong, with dancing and singing in the form of ceremonial singing. In addition, there are also many interesting folk games in the festival such as swinging, puppetry, kicking, chirping, drumming, ...

In the March period, not only Hung Temple in Co Tich village, but according to statistics, 1,000 communes in the midlands Phu Tho, Vinh Phuc, Hoa Binh, Ha Tay (old), Bac Ninh, Bac Giang had about 1,200 monuments worshiping King Hung and his generals, everywhere jubilantly celebrated the death anniversary of King Hung. Although the festival took place in various forms, mixed with local customs and beliefs, the main content was to commemorate the merits of Hung Kings. The Nôm sentence at the entrance to Ha Temple has concisely summarized the meaning of the death anniversary of Hung Vuong Fatherland.

Every year, Tam's Tomb, Tan mountain, Da river, still converts to the ancestral land.

In a new civilization, the children of Hong and the children of Lac can remember his grave.

Worshiping Vietnamese ancestors in the Northern Delta is a beauty in community cultural activities. Depending on the scene, depending on the time, the anniversaries of ancestors, ancestors, village associations and patriarchs are celebrated simply or solemnly. But whether simple or solemn, we also take the mind, the "religion" as the head and follow a certain system. It is possible to model the Vietnamese ancestor worship system in the Northern Delta as follows:

The entire Vietnamese ethnic community is underpinned by the common belief of a "fellow citizen" source, all of which are "descendants of the Lac and the Red". And that is also the strength that helps our people to be stable against all the threats of foreign invaders. During the fifteenth and sixteenth centuries until now, when Hung Vuong was considered the fatherland, this consciousness played a very important role in the spiritual life of the nation.

The leader was originally named Hung King by legend and was Han turned to Hung Vuong, and established a temple on Nghia Linh mountain (Phu Tho). When Dai Viet was established, the dynasties held festivals. From the reign of King Le Thanh Ton, the reign of Hong Duc (1470-1497) has prescribed international rites (sacrifice according to national rites). Today, the National Assembly of Vietnam has issued a resolution recognizing the Hung Temple ceremony as a national ceremony. The Hung Temple Festival is the biggest and popular festival in the country. At present, around Hung Temple, there are hundreds of villages with communal houses, to worship King Hung, and in the South there are many places to set up the Temple of Hung King and the concubines.

Every year, millions of people from all over the country come to celebrate this Patriarch's Day. Places that 
cannot be returned have "hope". The state restored and Hung Temple was enlarged in both scale and mode of worship.

The morality towards the roots, towards those who have merit to create life for the Vietnamese people, is also the ethic towards the common origin of the nation. Love for the motherland, love for the country is also fused from here. To respect our ancestors is to honor Mother Au Co, to King Hung "who has made the country". Patriotism and national pride are a precious and cross-cutting moral value that has a directional meaning for the Vietnamese people's life.

Hung Vuong worshiping beliefs go back to ancient times and have become a cultural identity of the Vietnamese community. Wherever you go, where you go, every Vietnamese person always looks to the roots and to the ancestors with gratitude and gratitude. Because of that, worshiping Hung Vuong has been and is strongly spreading, becoming a strong glue that attaches the meaning of "fellow citizens".

Hung Vuong 's worship beliefs belong to Vietnamese ancestors' culture and beliefs. The ancestor worship of the Vietnamese nation is the "drink water, remember its source", in which, Hung Vuong worshiping belief is very unique and has a lively meaning that no other people in the world have. In the historical process, Hung Vuong worship belief has always been an internal element of the national culture, contributing to foster pride, creating a spirit of solidarity and patriotism of the Vietnamese people.

Worshiping Hung Vuong is not a religion, Hung Kings is not the lord, Vietnamese worshiping Hung Vuong has no doctrine and no propaganda church, but for thousands of generations, Vietnamese people still practice. Incense to Hung Temple to pay tribute to the merits of Hung Kings, who have built the country, laying the foundation for the Vietnamese nation to endure forever. From that fact, Hung Vuong worshiping belief has existed and developed in the Vietnamese community for thousands of years and has become a unique cultural activity in the spiritual life of the Vietnamese people.

On the way of developing the country in the context of globalization, life is quite chaotic with so many joys and worries, so many gains and losses. River festival, the sacred death anniversary reminds us to keep our oath: protect the country.

For Vietnamese people, the death anniversary of Hung King's ancestors has always been respected, it is a tribute and a return to the origin of the nation. From the legend of a hundred-egg fetus to the legend of Hung Vuong, the Vietnamese have built up for their ancestor a complete record, even a day of death. According to Toan Anh, "in the past, every year at the Temple of Hung King in Fairy village, Lam Thao district, Phu Tho province, there were international organizations and representatives of the court to stand presiding at the death anniversary. People from different places came to Hung temple to worship the ancestors and even the provinces also prayed to King Hung ". Therefore, it is the most important anniversary of the Vietnamese people's death: Anyone who goes back and forth / Remember the anniversary of the 10th anniversary of March.

The October of March every year has become the anniversary of the death anniversary of King Hung, a gathering day for descendants from all parts of the country towards the ancestral land. It can be said that Hung Vuong's death anniversary is an abstraction of the sense of origin, deeply rooted in ancestor worship in the village, in the family and in the family. The philosophy of national origin has also played an important part in the theoretical consolidation of kinship relations. House and water, water and house, if the water dies, the house melts, the rich people will be strong. Therefore, the ancestor worship of Vietnamese people from family, lineages to the Fatherland has been constantly preserved through the ups and downs of history, despite all schemes and assimilation of assimilation. invaders

\section{Conclusion}

Ancestor worship of Vietnamese people is both unconscious, both the subconscious and the consciousness of each individual and the community. It is a spiritual culture that is both indigenous and human and is "inherited socially" from generation to generation. The ancestor worship can be considered as a kind of cultural "gene" of the Vietnamese people, is a universal traditional belief form of the Vietnamese people. As a Vietnamese, "everyone worshiped Hung Vuong".

\section{REFERENCES}

1. Toan Anh (1996), Vietnamese family worship customs, publishing company Native culture, Ha Noi.

2. Phan Ke Binh (1995), Vietnamese customs, publishing company Ho Chi Minh City, page.

3. Communist Party of Vietnam (2011), Document of the XI National Party Congress, publishing company Hanoi National Politics. 